\title{
Degradation of connective tissue components by lung derived leucocytes in vitro: role of proteases and oxidants
}

\author{
GERALDINE M BROWN, K DONALDSON \\ From the Institute of Occupational Medicine, Edinburgh
}

ABSTRACT Inflammatory leucocytes are implicated in connective tissue damage during chronic ${ }_{\circ}^{\mathrm{N}}$ inflammatory lung disease. In an investigation of the role of leucocytes in connective tissue ${ }^{\circ}$ derangements in the lung, inflammatory leucocytes were generated in rat lungs by intratracheal $\overrightarrow{T r}$ instillation of inflammatory agents and retrieved by bronchoalveolar lavage. The proteolytic $\frac{\mathbb{D}}{O}$ activities of control macrophages and of two inflammatory cell populations were compared; iodinated collagen, laminin, and fibronectin matrices were used. The inflammatory cells caused $₹$ consistently and substantially more degradation of the matrices than the controls on a per cell basis. $\vec{\oplus}$ The oxidant scavengers superoxide dismutase and catalase did not inhibit matrix degradation, but $\alpha_{1} \infty$ protease inhibitor and $\alpha_{2}$ macroglobulin were inhibitory. It is concluded that matrix damage in this assay is enhanced by inflammatory cells and is mediated principally by serine protease activity.

Accumulation of inflammatory leucocytes in the alveolar region of the lung is characteristic of disorders leading to fibrosis or destruction of lung parenchyma; inflammatory macrophages and polymorphonuclear leucocytes have been implicated in the pathogenesis of both types of disease. ' In the adult respiratory distress syndrome large numbers of polymorphonuclear leucocytes (neutrophils) accumulate in the alveoli and are believed to have a major role in the disease process. $^{2}$ In interstitial lung fibrosis alveolitis is the initiating event in a process that leads, ultimately, to remodelling of the lung parenchyma. ${ }^{3}$ Inflammatory cells are also implicated in the degradation of lung tissue and subsequent loss of alveoli in emphysema. ${ }^{4}$

Polymorphonuclear leucocytes and activated macrophages secrete proteases and reactive oxygen intermediates at sites of inflammation ${ }^{56}$ and, although beneficial during short term inflammation, the persistence of increased numbers of inflammatory cells in the alveolar region may lead to an excessive burden of these products. Indeed, concentrations of proteases are raised in the bronchoalveolar lavage fluid of patients with adult respiratory distress syndrome, ${ }^{7}$ idiopathic pulmonary fibrosis, ${ }^{8}$ and sarcoidosis. ${ }^{9}$

Address for reprint requests: Dr Geraldine M Brown, Institute of Occupational Medicine, Edinburgh EH8 9SU.

Accepted 5 November 1987
Proteolytic enzymes and oxidants can damage connec- $\stackrel{\mathbb{Q}}{\circ}$ tive tissue components in vitro ${ }^{10-13}$ and in vivo. ${ }^{14}$ Thus $\overrightarrow{\vec{\circ}}$ structural derangements of the lung parenchyma that 3 occur during chronic inflammatory lung disease may? be mediated by inflammatory cell derived proteases and reactive oxygen intermediates.

In the present study we have measured the ability of으 lung derived macrophages and polymorphonuclear leucocytes to degrade connective tissue components ino vitro. We prepared iodinated matrices, using connec 3 . tive tissue components that occur in lung basemento membrane and extracellular matrix. Proteolytic $₹$ activity was assessed by measuring degradation of the응 matrices by three populations of lung derived $>$ leucocytes - control and two populations of inflam-을. matory cells. To assess the role of proteases and oxidants in matrix degradation, we examined the inhibitor profile of matrix destruction caused by the $N$ three cell populations, using protease inhibitors and స్తు oxidant scavengers.

\section{Methods}

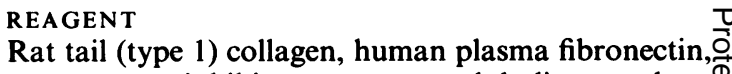

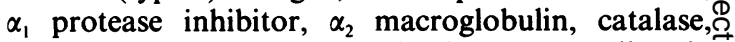
superoxide dismutase, and bovine serum albumin $\stackrel{\Omega}{\Omega}$ were obtained from the Sigma Chemical Companyo (Poole, Dorset). Mouse laminin, phosphate buffered 
saline (PBS) and serumless medium ( $\mathrm{N}$ and $\mathrm{T}$ ) were purchased from Gibco BRL (Paisley, Renfrewshire). Ethylene diamine tetra-acetic acid (EDTA) was obtained from BDH, Poole, Dorset, and Corynebacterium parvum from Wellcome Reagents Ltd (Hither Green, London). Iodine-125 ( $\left.{ }^{125} \mathrm{I}\right)$ was purchased from Amersham International (Aylesbury, Buckinghamshire). The quartz used was the $\mathrm{DQ}_{12}$ standard sample.

\section{ANIMALS}

Specific pathogen free, syngeneic, female $P V G$ rats were obtained from the breeding unit of the Institute of Occupational Medicine, Edinburgh.

\section{CELl PREPARATIONS}

Production of inflammatory cells was induced in rat lungs by intratracheal instillation of $1 \mathrm{mg} C$ parvum or quartz cells were retrieved by bronchoalveolar lavage of the resected lungs 16 hours after $C$ parvum or five days after quartz instillation; control cells were obtained similarly from untreated rats. The resected lungs were cannulated with a blunt $16 \mathrm{G}$ needle and lavaged with four sequential $8 \mathrm{ml}$ volumes of saline at $37^{\circ} \mathrm{C}$. The lungs were gently massaged during each wash and the recovered lavage fluid $(5 \mathrm{ml}$ from the first lavage, 6-7 $\mathrm{ml}$ thereafter) was pooled in plastic universal containers and placed immediately on ice. The bronchoalveolar lavage cells were pelleted by centrifugation at $800 \mathrm{~g}$, washed once in $30 \mathrm{ml}$ of ice cold PBS and resuspended in the appropriate medium for the assay. To ensure that non-specific activation did not occur, the cells were kept ice cold throughout the preparation procedure and all manipulations were carried out with plastic pipettes and containers.

\section{SUBSTRATE IODINATION AND MATRIX}

\section{PREPARATION}

Collagen, laminin, and fibronectin were iodinated by the method of McConahey and Dixon, ${ }^{16}$ except that Lcysteine was substituted for sodium meta-bisulphite. Unbound iodine was removed by chromatography on a Sephadex G25 column (PD10, Pharmacia, Milton Keynes, Bucks). The labelled proteins showed activities of $5-25 \times 10^{6} \mathrm{cpm} / \mu \mathrm{g}$ protein. Collagen labelled with iodine-125 ( $\left.{ }^{125} \mathrm{I}\right)$ was diluted in $0.1 \mathrm{M}$ acetic acid and $100 \mu \mathrm{l}$ aliquots $(10000 \mathrm{cpm})$ were placed in microtitre removawells and dried on at $45^{\circ} \mathrm{C}$, a temperature at which collagen is denatured to gelatin. Laminin labelled with ${ }^{125} \mathrm{I}$ was diluted in PBS and $10000 \mathrm{cpm}$ aliquots were dried on to removawells as above; ${ }^{125}$ I fibronectin was also diluted in PBS and $40000 \mathrm{cpm}$ aliquots similarly dried onto removawells.
PROTEOLYSIS ASSAY

All assays of fibronectin proteolysis were carried out in $\mathrm{N}$ and $\mathrm{T}$ medium containing $2 \%$ bovine serum albumin; $\mathrm{N}$ and $\mathrm{T}$ medium without bovine serum albumin was used in the collagen and laminin degradation experiments. To reduce background counts, the removawells coated with ${ }^{125}$ I substrate were presoaked for two hours immediately before use with $200 \mu \mathrm{l}$ of assay medium alone and were then washed once with $300 \mu \mathrm{l}$ of PBS. In all experiments except the doseresponse study of fibronectin proteolysis, $1 \times 10^{5}$ cells were added to each removawell in a final volume of 200 $\mu \mathrm{l}$ medium. In all but the dose $(6 \mathrm{~h})$ and time response of fibronectin proteolysis, matrix degradation was assessed following four hours' incubation at $37^{\circ} \mathrm{C}$. To assess release of ${ }^{125} \mathrm{I}$ labelled degradation products, 150 $\mu \mathrm{l}$ of supernatant medium was harvested from each well and counted by gamma counter.

\section{INHIBITORS}

The role of oxidants in matrix degradation was assessed in inhibition studies, the hydrogen peroxide scavenger catalase and superoxide dismutase, a scavenger of superoxide anion, being used. Similarly, the role of proteases was assessed by means of the protease inhibitors $\alpha_{1}$ protease inhibitor and $\alpha_{2}$ macroglobulin. Catalase, superoxide dismutase, and $\alpha_{1}$ protease inhibitor were tested at final concentrations of $0.01,0.1$ and $1.0 \mathrm{mg} / \mathrm{ml} ; \alpha_{2}$ macroglobulin was used at $0.005,0.05$, and $0.5 \mathrm{mg} / \mathrm{ml}$.

\section{STATISTICAL ANALYSIS}

The effect of inhibitors on fibronectin matrix degradation was analysed by means of the Genstat linear interpolation program. ${ }^{17}$ All other results were assessed by analysis of variance; the Minitab statistical package was used. The significance of differences between mean values at specific times and concentrations were tested by Student's $t$ test.

\section{Results}

BRONCHOALVEOLAR LAVAGE CELl POPUlations Both groups of treated rats showed alveolar inflammation, evidenced by greater numbers of cells in the bronchoalveolar lavage fluid compared with controls and by changes in the proportion of cells present (fig 1). In the control population the average yield of cells per rat was 7.5 (SEM 2.0$) \times 10^{6}$, of which over $95 \%$ were macrophages and the remainder lymphocytes. The population of cells elicited by $C$ parvum showed the greatest increase in cell numbers-to $62.6(22 \cdot 1) \times$ $10^{6}$, of which over $75 \%$ were neutrophils, about $20 \%$ macrophages, and about $2 \%$ lymphocytes. Cell numbers in the quartz lavage fluid were also greater than in the control lavage fluid-23.78 (7.26) $\times 10^{6}$, of which 

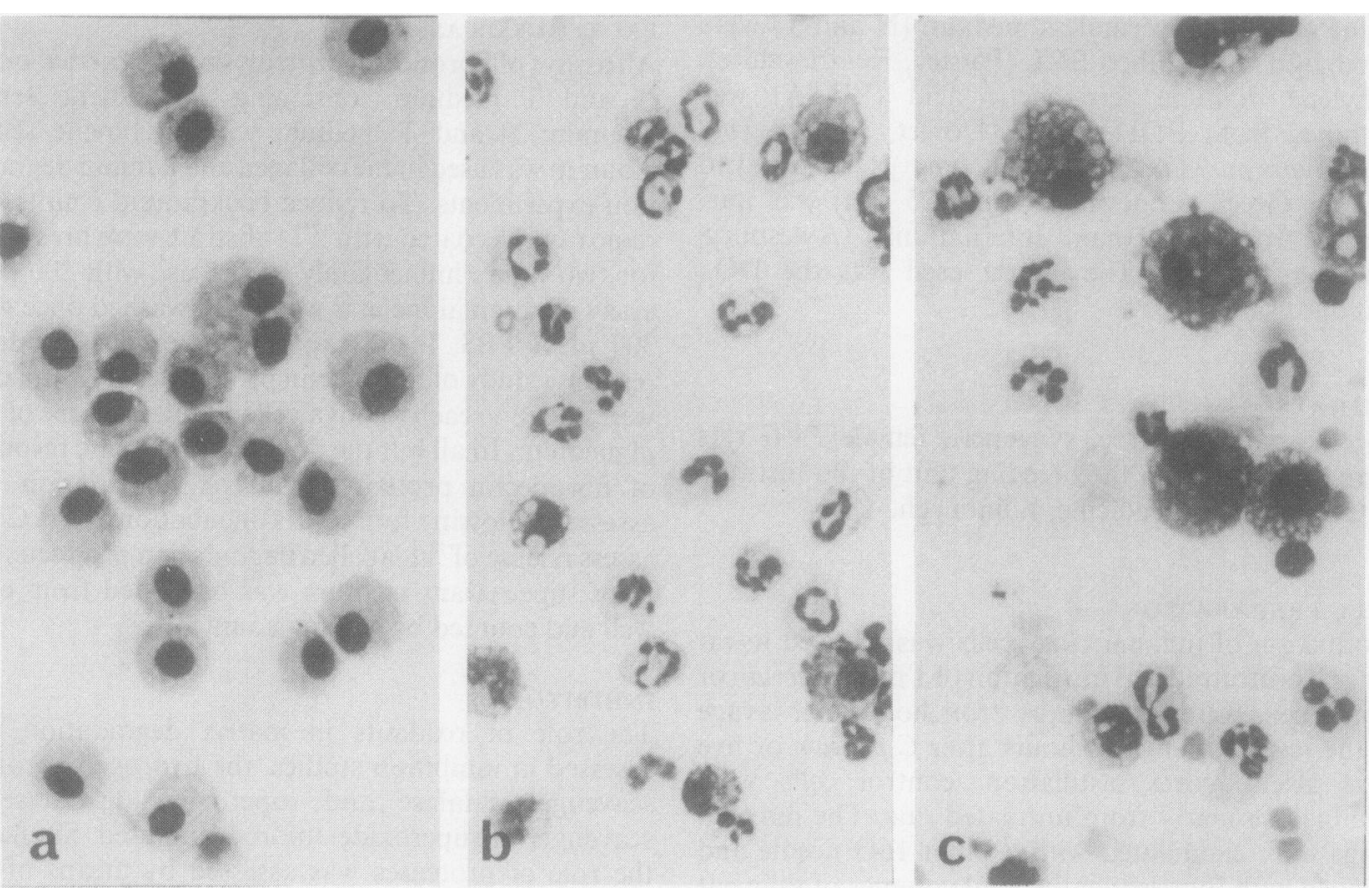

Fig 1 Bronchoalveolar lavage populations from rat lungs. (a) Control cells ( $>95 \%$ macrophages); (b) Corynebacterium parvum elicited cells ( $>75 \%$ leucocytes, $\simeq 20 \%$ macrophages, $\simeq 2 \%$ lymphocytes); (c) quartz elicited cells $(\simeq 50 \%$ macrophage,$\simeq 50 \%$ polymorphs $)$.

about half were neutrophils and about half macrophages.

\section{VALIDATION OF MATRIX DEGRADATION ASSAY}

Proteolysis of fibronectin, denatured collagen, and laminin matrices were assessed in preliminary validation experiments with the enzymes trypsin, elastase, and collagenase. The matrices were equally susceptible to dose dependent proteolysis by the three enzymes (results not published).

\section{DOSE-RESPONSE STUDY}

The proteolytic activity of each lavage population was assessed at four concentrations $(0.001,0.01,0.1$, and $1.0 \times 10^{5}$ cells/well) with an ${ }^{125}$ I fibronectin matrix, andoall showed some ability to degrade the matrix (fig 2)

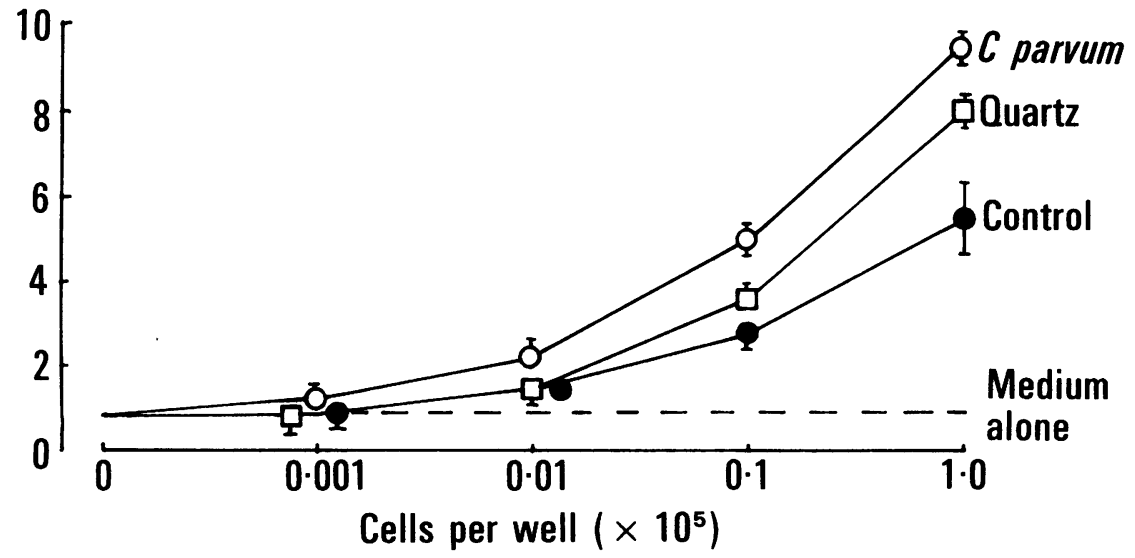

Fig 2 Dose-response relationship of fibronectin matrix degradation by control cells and cells elicited by Corynebacterium parvu迎 and quartz: counts released into the medium after six hours' incubation. Results $\stackrel{+}{+}$ are the means and standardo errors of three experiment $\mathrm{D}$. with triplicate samples in each. 
The degradative capacity of each cell population increased in a dose dependent manner. The release of ${ }^{125}$ I degradation products by the control and quartz populations was significantly greater than the background level only at concentrations of 0.1 and $1.0 \times$ $10^{5}$ cells/well (controls $\mathrm{p}<0.0025$ and $\mathrm{p}<0.005$ respectively, quartz $p<0.005$ ); but at $1 \times 10^{5}$ cells/ well the amount of radioactivity released by the quartz cells was almost double that of the control cells. The cells elicited by $C$ parvum were more actively proteolytic than either the control or the quartz elicited cells, releasing significantly more radioactivity than the background level at $0.01 \times 10^{5}$ cells/well $(p<0.025)$. Although the cells elicited by $C$ parvum caused greater matrix proteolysis than the quartz population at each cell concentration, the difference between the two populations of inflammatory cells was significant only at a concentration of $0.1 \times 10^{5}$ cells/well $(p<0.005)$.

\section{TIME-RESPONSE STUDY}

The three lavage cell populations were tested at a concentration of $1 \times 10^{5}$ cells/well for periods of $2,4,6$ and 24 hours with an ${ }^{125}$ I fibronectin matrix. Each cell population produced significantly more release of radioactivity than medium alone at every time point (p $<0.025-<0.005$ ) (fig 3$)$. The proteolytic activity of all three lavage cell populations showed a time dependent increase, which continued up to 24 hours for both inflammatory populations, but plateaued at 6 hours with the controls. Both inflammatory populations were significantly more active than the controls at all time points $(\mathrm{p}<0.01-\mathrm{p}<0.005)$ and similarly the cells elicited by $C$ parvum were significantly more active than the quartz elicited cells at each time point $(\mathrm{p}<0.025-<0.005)$.

\section{DENATURED COLLAGEN AND LAMININ}

In addition to fibronectin, we tested the proteolytic activity of the lavage cells with two alternative connective tissue components that occur in lung extracellular matrix-laminin and denatured collagen. As with fibronectin degradation, the two inflammatory cell populations caused greater proteolysis of collagen and laminin than control cells, and collagen degradation produced by $C$ parvum elicited cells was greater than that produced by quartz elicited cells (fig 4); but there was no difference in laminin degradation between $C$ parvum and quartz elicited cells.

\section{ROLE OF PROTEASES AND OXIDANTS}

To examine the role of proteases and oxidants in matrix degradation, we studied the effect of protease inhibitors and oxidant scavengers on the proteolysis of a fibronectin matrix produced by control cells and by cells elicited by $C$ parvum and quartz. The oxidant scavengers superoxide dismutase and catalase had no effect on the matrix proteolysis caused by any of the lavage cell populations (fig 5). Similarly, the protease inhibitors $\alpha_{1}$ protease inhibitor and $\alpha_{2}$ macroglobulin had no effect on control cell proteolysis but caused a dose dependent reduction in matrix proteolysis by both inflammatory cell populations (table). $\alpha_{1}$ protease inhibitor was equally effective in inhibiting matrix proteolysis by $C$ parvum and quartz elicited cells, causing a significant reduction of both cell populations at 0.1 and $1 \mathrm{mg} / \mathrm{ml}(\mathrm{p}<0.001)$ and at $0.01 \mathrm{mg} / \mathrm{ml}$ $(p<0 \cdot 01) . \alpha_{2}$ macroglobulin significantly reduced

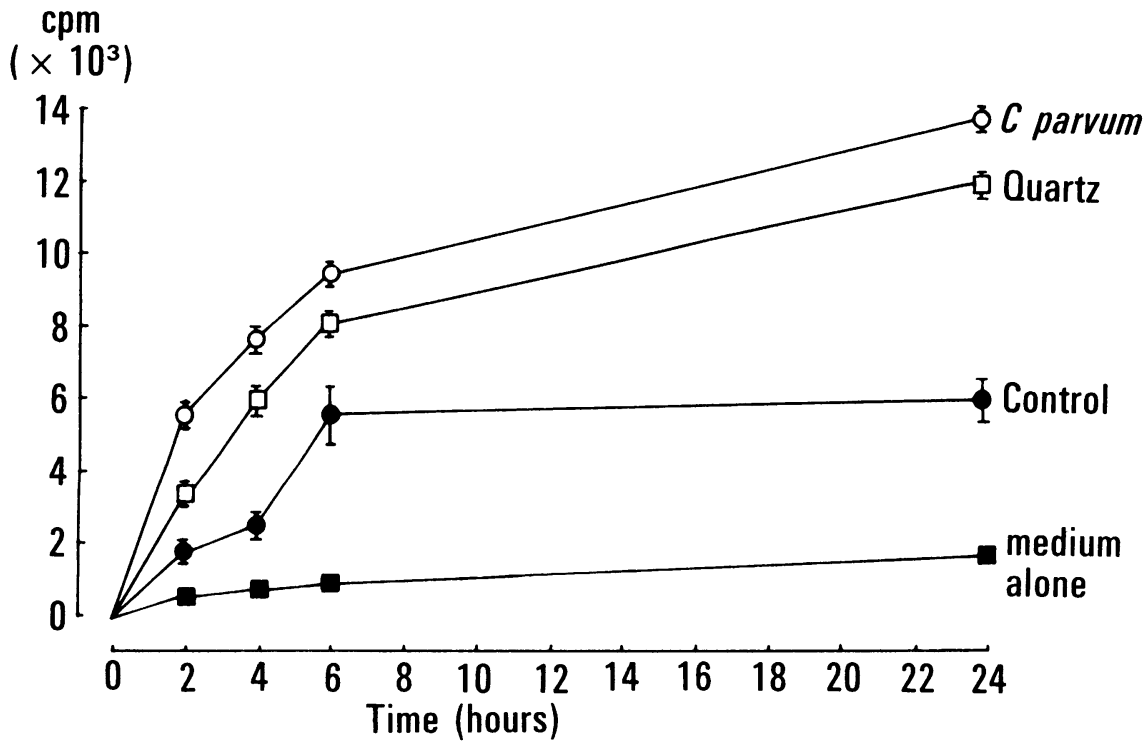

Fig 3 Time response of fibronectin matrix degradation by control cells and cells elicited by Corynebacterium parvum and quartz: counts released into the medium by $1 \times 10^{5}$ cells per well. Results are the means and standard errors of three experiments, with triplicate samples in each. 


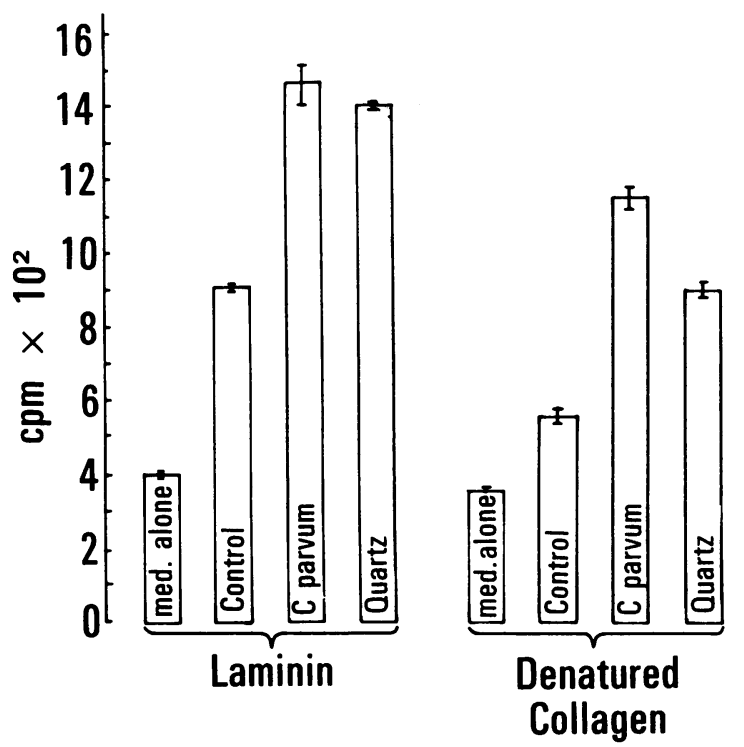

Fig 4 Degradation of laminin and denatured collagen matrices: counts released into the medium by control cells and cells elicited by Corynebacterium parvum and quartz after four hours' incubation with $1 \times 10^{5}$ cells per well. Results are the means and standard errors of three experiments, with triplicate samples in each.

fibronectin matrix proteolysis by the quartz elicited cells at $0.05 \mathrm{mg} / \mathrm{ml}(p<0.05)$ and $0.5 \mathrm{mg} / \mathrm{ml}$ $(p<0.001)$ but was less effective in reducing proteolysis produced by $C$ parvum elicited cells, achieving a statistically significant effect only at a concentration of $0.5 \mathrm{mg} / \mathrm{ml}(\mathrm{p}<0.001)$.

\section{Discussion}

The aim of the present study was to assess the role of $\frac{\bar{c}}{\bar{c}}$ inflammatory leucocytes in connective tissue damage in the lung and to examine the relative contributions of reactive oxygen intermediates and proteases to thises damage.

The connective tissue components collagen, laminin, and fibronectin occur extensively in the lung $\vec{\omega}$ parenchyma ${ }^{18}$ and have diverse properties, relevant to? normal lung functioning, which may be altered during $x$ chronic lung disease. ${ }^{1920}$ Alteration of the conforma- $-\vec{\omega}$ tion of connective tissue structure leads to the loss off basement membrane ${ }^{21}$ and breakdown of cell to celliw and cell to matrix interactions, ${ }^{22-27}$ which are impor- ${ }^{\mathrm{N}}$ tant in growth control and the maintenance of normal tissue structure. In addition, protease generated con $-\vec{T}$ nective tissue fragments are chemotactic ford leucocytes. ${ }^{2829}$ Thus proteolytic damage to connective tissue may enhance and prolong the inflammatory process and lead ultimately to fibrosis or emphysema. ${ }^{20}$

In this study, we assessed the ability of lung derived inflammatory cells to damage connective tissue components normally present in lung extracellular matrix and basement membrane. All matrices wereo susceptible to damage by control and inflammatoryo bronchoalveolar leucocytes, the latter being con- $\AA$ sistently and substantially more active. Fibronectin degradation by the control cell population plateaued 3 by 6 hours, which may indicate a transient activation? of the cells during preparation. On a per cell basis, the quartz population produced twice as much neutraf protease as the controls and the $C$ parvum population three times more than the controls. The increased

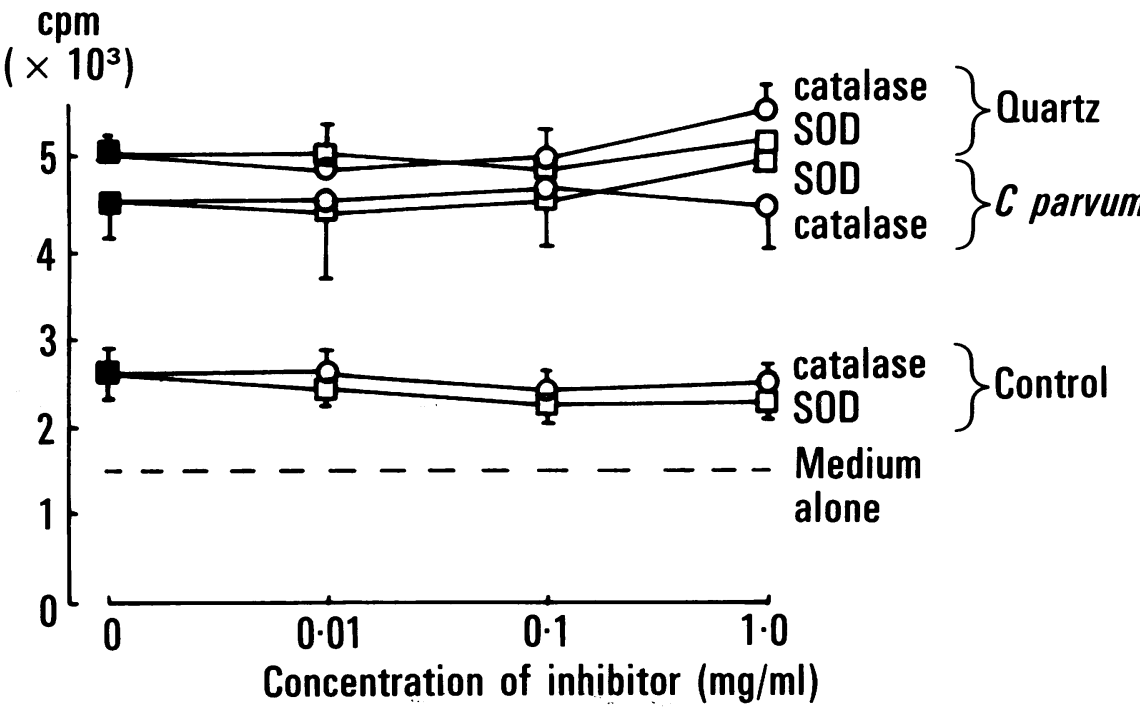

Fig 5 Dose-response relationship of the effect of the oxidant scavengers superoxide dismutase $\mathrm{N}$ (SOD) and catalase on degradation of a fibronect matrix by control cells andw cells elicited by Corynebacterium parvum and quartz. Results are the means and standard errors three experiments, with triplicate samples in each. no inhibitor. 
Degradation of a fibronectin matrix by control bronchoalveolar cells and those elicited by Corynebacterium parvum and quartz in the presence of the protease inhibitors $\alpha_{1}$ protease inhibitor and $\alpha_{2}$ macroglobulin (results (means $(S E M)$ ) derived from triplicate samples in three separate experiments)

\begin{tabular}{lllll}
\hline Inhibitor & $\begin{array}{l}\text { Final } \\
\text { conc } \\
(\mu \mathrm{g} / \mathrm{ml})\end{array}$ & $\begin{array}{l}\text { Control } \\
\text { cells }\end{array}$ & $\begin{array}{l}\text { Cparvum } \\
\text { elicited } \\
\text { cells }\end{array}$ & $\begin{array}{l}\text { Quartz } \\
\text { elicited } \\
\text { cells }\end{array}$ \\
\hline None & & $2603(299)$ & $4587(456)$ & $5108(304)$ \\
$\alpha_{1}$ protease inhibitor & 0.01 & $2380(251)$ & $2885(569)^{* *}$ & $3963(374)^{* *}$ \\
& $0 \cdot 1$ & $2428(261)$ & $2795(379)^{* *}$ & $3260(335)^{* * *}$ \\
$\alpha_{2}$ macroglobulin & $1 \cdot 0$ & $2333(235)$ & $2097(230)^{* * *}$ & $2531(274)^{* * *}$ \\
& 0.005 & $2787(321)$ & $4298(418)$ & $4648(335)$ \\
& 0.05 & $2456(281)$ & $4157(571)$ & $4198(348)^{* *}$ \\
\hline
\end{tabular}

**Significant reduction compared with no inhibitor: $p<0.01$.

*** Significant reduction compared with no inhibitor: $p<0.001$.

protease appeared to be related to an increased proportion of neutrophils in the bronchoalveolar lavage fluid. Recalculation of the data on the basis of the differential cell count suggested that the neutrophils in the two inflammatory populations were secreting similar amounts of neutral protease; this was estimated to be five times more than the amount secreted by the bronchoalveolar macrophages.

To determine the nature of the process of matrix degradation, we tested the effects of inhibitors of protease and of reactive oxygen intermediates in the assay. In vitro studies have suggested that reactive oxygen intermediates may be important in connective tissue damage,${ }^{30}{ }^{31}$ but in our assay neither catalase nor superoxide dismutase reduced matrix proteolysis, thus indicating that neither hydrogen peroxide nor superoxide anion are involved in damage to the extracellular matrix. These results are in general agreement with the findings of several in vitro studies discounting reactive oxygen intermediates as a source of extracellular matrix degrading activity, ${ }^{1032} 33$ although in one study $\mathrm{H}_{2} \mathrm{O}_{2}$ was implicated. ${ }^{32}$ To confirm that oxidant injury did not contribute to matrix proteolysis in the present study we tested exogenous hydrogen peroxide and superoxide anion and no proteolysis occurred (results not published). These results are in agreement with the findings of a previously published study in this laboratory, which indicated that reactive oxygen intermediates are not a major arbiter of tissue injury in mineral dust inflammation. ${ }^{33}$

To elucidate the mechanisms of proteolysis further we examined the inhibitor profile of the three cell populations, using protease inhibitors. The low level of proteolysis shown by control cells could not be inhibited, possibly owing to the presence of cysteine protease ${ }^{34}$ or to exclusion of soluble inhibitors from sites of close contact between leucocytes and the extracellular matrix. ${ }^{1035} 36$

The $C$ parvum population ( $>95 \%$ neutrophils) and the quartz population $(50 \%$ neutrophils, $50 \%$ macro- phages) showed similar inhibition profiles in response to $\alpha_{2}$ macroglobulin and to $\alpha_{1}$ protease inhibitor. Macrophage neutral proteases have been reported to be largely metalloprotease ${ }^{37}{ }^{38}$ and thus not capable of inhibition by $\alpha_{1}$ protease inhibitor. ${ }^{39}$ The inhibition profiles of the two inflammatory populations should therefore have been different in terms of their response to $\alpha_{1}$ protease inhibitor if the macrophages in the quartz population were secreting metalloproteases. Since $\alpha_{1}$ protease inhibitor inhibited the two inflammatory populations to the same extent, we tested inhibition of exogenous serine protease (porcine elastase) and metalloprotease (bacterial collagenase) in the fibronectin assay and confirmed that in our assay system serine proteases but not metalloproteases were inhibited by $\alpha_{1}$ protease inhibitor (results not published). These results suggest that the proteolytic activity of the quartz population may be due to a serine protease, or to cysteine proteases as suggested above.

In summary, we have elicited two distinct populations of inflammatory cells in rat lungs, one containing largely neutrophils and the other composed equally of macrophages and neutrophils. The proteolytic activity of the two populations of inflammatory cells in vitro was substantially greater on a per cell basis than that of control bronchoalveolar cells. By carrying out inhibitor studies we have discounted the role of reactive oxygen intermediates in matrix degradation and have indicated that the proteolysis is mediated by serine protease activity.

Our results show that inflammatory leucocytes from the bronchoalveolar region of the lung have substantial connective tissue proteolytic activity; we have also shown that this activity can be inhibited by $\alpha_{2}$ macroglobulin and $\alpha_{1}$ protease inhibitor. These two inhibitors are found in the alveolar region of the lung, but the presence of active proteases in the bronchoalveolar lavage fluid of patients with chronic lung disease $^{7-9}$ suggests that the presence of large numbers of inflammatory cells in the lung parenchyma overloads this antiprotease screen. Protease activity 
derived from inflammatory leucocytes may thus be a major arbiter of connective tissue damage during chronic inflammatory lung disease.

This work was funded in part by the Colt Foundation. We wish to thank Professor D M Weir for his continued interest in the project.

\section{References}

1 Hunninghake GW, Gadek JE, Kawanami O, Ferrans VJ, Crystal RG. Inflammatory and immune processes in the human lung in health and disease: evaluation by bronchoalveolar lavage. Am J Pathol 1979;97:149206.

2 Weiland JE, Davis WB, Holter JF, Mohammed JR, Dorinsky PM, Gadek JE. Lung neutrophils in the adult respiratory distress syndrome. Clinical and pathophysiologic significance. Am Rev Respir Dis 1986;133:218-25.

3 Keogh BA, Crystal RG. Alveolitis: the key to the interstitial lung disorders. Thorax 1982;37:1-10.

4 Gadek JE, Fells GA, Zimmerman RL, Crystal RG. Role of connective tissue proteases in the pathogenesis of chronic inflammatory lung disease. Environ Health Perspect 1984;55:297-306.

5 Janoff A, White R, Carp H, Harel S, Dearing R, Lee D. Lung injury induced by leukocytic proteases. $\mathrm{Am} \mathrm{J}$ Pathol 1979;97:111-35.

6 Fantone JC, Ward P. Mechanisms of lung parenchymal injury. Am Rev Respir Dis 1984;130:484-91.

7 Christner P, Fein A, Goldberg S, Lippman M, Abrams W, Weinbaum G. Collagenase in the lower respiratory tract of patients with adult respiratory distress syndrome. Am Rev Respir Dis 1985;131:690-5.

8 Gadek JE, Kelman JA, Fells GA, et al. Collagenase in the lower respiratory tract of patients with idiopathic pulmonary fibrosis. N Engl J Med 1979;301:737-42.

9 O'Connor C, Power C, Ward K, Fitzgerald MX. Markers of collagen metabolism in BAL fluid from patients with sarcoidosis [abstract]. Thorax 1987;42:215.

10 Sibille P, Lwebuga-Mukasa JS, Polomski L, Merrill WW, Ingbar DH, Gee JBL. An in vitro model for polymorphonuclear leukocyte-induced injury to an extracellular matrix. Relative contribution of oxidants and elastase to fibronectin release from amnionic membranes. Am Rev Respir Dis 1986;134:134-40.

11 Borel JP, Monboisse JC, Ferradini C, et al. Collagen degradation under the influence of oxygen radicals. In: Rosso MF, ed. Advances in inflammation research. Vol 10. New York: Raven Press, 1985: 344-7.

12 McDonald JA, Baum BJ, Rosenberg DM, Kelman JA, Brin SC, Crystal RG. Destruction of a major extracellular adhesive glycoprotein (fibronectin) of human fibroblasts by neutral proteases from polymorphonuclear leukocytes. Lab Invest 1979;430:350-7.

13 Werb Z, Banda MJ, Jones PA. Degradation of connective tissue matrices by macrophages. 1. Proteolysis of elastin, glycoproteins and collagen by proteinases isolated from macrophages. J Exp Med 1980;152:1527 $\frac{\text { S }}{\frac{5}{0}}$ 36.

14 Riley DJ, Kerr JS. Oxidant injury of the extracellular matrix: potential role in the pathogenesis of pulmonary emphysema. Lung 1985;163:1-13.

15 Snider GL, Lucey EC, Stone PJ. Animal models of emphysema. Am Rev Respir Dis 1986;133:149-69.

16 McConahey PJ, Dixon FJ. A method of trace iodination $\vec{\circ}$ of proteins for immunological studies. Int Arch Allergy $\overrightarrow{\vec{\omega}}$ 1966;29:185-8.

17 Alvey NG, Banfield CF, Baxter RI, et al. Genstat $-a \stackrel{\rho}{\vec{\partial}}$ general statistical programme. Rothamsted: Rotham- $-x$ sted Experimental Station, 1977.

18 Hance AJ, Crystal RG. The connective tissue of lung. Amiv Rev Respir Dis 1975;112:657-711.

19 Riley DJ. Pulmonary connective tissue in occupational lung disease. In: Gee JBL, ed. Occupational lung응 disease. New York: Churchill Livingstone, 1984:1-23. -

20 Turino GM. The lung parenchyma - a dynamic matrix. T) Am Rev Respir Dis 1985;132:1324-34.

21 Vracko R. Significance of basal lamina for regeneration of injured lung. Virch Arch Ab A Pathol Anaई 1972;355:264-74. 22 McDonagh J. Fibronectin. A molecular glue. Arch Pathol $\vec{C}_{\infty}$
Lab Med 1981;105:393-6.

23 Holderbaum D, Ehrhart LA. Substratum influence on collagen and fibronectin biosynthesis by arterial smooth muscle cells in vitro. $J$ Cell Physiol 1986;126:216-24.

24 Lwebuga-Mukasa JS, Ingbar DH, Madri JA. Repopula- $\frac{\varrho}{8}$ tion of a human alveolar matrix by adult rat type II $\stackrel{\AA}{\varrho}$ pneumocytes in vitro. A novel system for type II $\overrightarrow{\vec{O}}$ pneumocyte culture. Exp Cell Res 1986;162:423-35.

25 Martin GR, Kleinman HK, Terranova VP, Ledbetter S, Hassell JR. The regulation of basement membrane formation and cell-matrix interactions by defined supramolecular complexes. In: Parkes R, Whelan J, eds. Basement membranes and movement. London: Pitman, 1984:197-212 (CIBA Foundation Symposium 108.)

26 Yamada KM. Fibronectin and other structural proteins. In: Hay ED, ed. Cell biology of extracellular matrix. New York: Plenum Press, 1982:95-113.

27 Yamada KM. Cell surface interactions with extracellular 윽 materials. Annu Rev Biochem 1983;52:761-99.

28 Postlethwaite AE, Kang AH. Collagen and collagen peptide-induced chemotaxis of human blood monocytes. J Exp Med 1976;143:1299-307.

29 Norris DA, Clark RAF, Swigart LM, Huff JC, Weston N WL, Howell SE. Fibronectin fragments are chemo- $\mathrm{N}$ tactic for peripheral blood monocytes. J Immunol $\omega$ 1982;129:1612-8.

30 Curran SF, Amoruso MA, Goldstein BD, Riley DJ, o Edelman NH, Berg RA. Degradation of soluble $\stackrel{\odot}{\varnothing}$ collagen. Possible mechanism of emphysema. Chest $\stackrel{\odot}{\rightarrow}$ 1984;85 (suppl):43-4S.

31 Greenwald RA, Moy WW. Effect of oxygen-derived free radicals on hyaluronic acid. Arth Rheum 1980;22: 455-63.

32 Shah SV, Baricos WH, Basci A. Degradation of human $\stackrel{\unrhd}{\unrhd}$ glomerular basement membrane by stimulated neutro- 
Degradation of connective tissue components by lung derived leucocytes in vitro

phils. Activation of a metalloproteinase. J Clin Invest 1987;79:25-31.

33 Donaldson K, Slight J, Bolton RE. Oxidant production by control and inflammatory bronchoalveolar leukocyte populations treated with mineral dusts in vitro. Inflammation (in press).

34 Chapman HA, Stone OL. Comparison of live human neutrophil and alveolar macrophage elastolytic activity in vitro. Relative resistance of macrophage elastolytic activity to serum and alveolar proteinase inhibitors. J Clin Invest 1984;74:1693-700.

35 Campbell EJ, Senior RM, McDonald JA, Cox DL. Relative importance of cell-substrate contact and oxidative inactivation of proteinase inhibitors in vitro. $J$ Clin Invest 1982;70:845-52.

36 Johnson KJ, Varani J. Substrate hydrolysis by immune complex-activated neutrophils: effect of physical presentation of complexes and protease inhibitors. $J$ Immunol 1981;127:1875-9.

37 Banda MJ, Werb Z. Mouse macrophage elastase. Purification and characterization as a metalloproteinase. Biochem J 1981;193:589-605.

38 White R, Habicht GS, Godfrey HP, Janoff A, Barton E, Fox C. Secretion of elastase and alpha-2macroglobulin by cultured murine peritoneal macrophages: studies on their interaction. $J$ Lab Clin Med 1981;97:718-29.

39 Vaes G. Macrophage secretory products and connective tissue remodelling: role of macrophage enzymes and of "matrix regulatory monokines." In: Dean LT, Stabe P, eds. Developments in cell biology. 1-Secretory processes. London: Butterworths, 1985:99-117. 